Article

\title{
Political Representation in the Discourse and Practices of the "Party of the Common Man" in India
}

\author{
Stéphanie Tawa Lama-Rewal \\ Centre d'Etudes de I'Inde et de l'Asie du Sud, Centre National de la Recherche Scientifique, 75006 Paris, France; \\ E-Mail: tawalama@ehess.fr
}

Submitted: 28 March 2019 | Accepted: 28 June 2019 | Published: 24 September 2019

\begin{abstract}
One of the many challenges presented by populism concerns its relationship with political representation. What happens when an anti-politics movement wins elections? This article offers an analysis of the exercise of power by the Aam Aadmi Party (AAP, Party of the Common Man), which has been ruling the city-state of Delhi since 2015, in order to bring elements of answer to this question. On the basis of discourse analysis as well as direct observation of meetings, the article first identifies a series of populist tropes in the official discourse of the AAP, including a de-emphasis on representation to the advantage of participation. It then describes the two main participatory schemes implemented by the AAP government since 2015, and shows that these generate, in different ways, a magnification of the mediation work that is central to political representation at the local level in the Indian context. Finally, the article argues that the party has been developing, through these participatory schemes, a form of "inclusive representation" (Hayat, 2013), in which inclusion is linked to mobilization.
\end{abstract}

\section{Keywords}

Aam Aadmi Party; India; mediation; participatory democracy; political representation; populism

\section{Issue}

This article is part of the issue "Rethinking Representation: Representative Claims in Global Perspective", edited by Petra Guasti (Goethe University Frankfurt, Germany) and Brigitte Geissel (Goethe University Frankfurt, Germany).

(C) 2019 by the author; licensee Cogitatio (Lisbon, Portugal). This article is licensed under a Creative Commons Attribution 4.0 International License (CC BY).

\section{Introduction}

One of the many challenges presented by populism to its observers concerns its relationship with political representation. If "the populist ideology fosters a particular mode of political representation" (Kaltwasser, 2014, p. 484), then what do we know about it, at a time when an increasing number of political projects and regimes across the world are being qualified as "populist"? In order to bring elements of answer to this question, this article analyses the exercise of power by the Aam Aadmi Party (AAP, Party of the Common Man), which has been ruling the city-state ${ }^{1}$ of Delhi since 2015 . The AAP was born from an anti-politics movement, "India Against
Corruption" (2011-2012), that vehemently denounced misrepresentation. What happens, then, when this type of anti-politics movement wins elections?

In an article interpreting the "contending representative claims" put forward in the 2014 general elections in India, Niraja Gopal Jayal argues that the AAP's representative claim is a populist one. Indeed she considers that the AAP and Narendra Modi's Bharatiya Janata Party (BJP; Indian People's Party) together bring about "a shift from one dominant type of representative claim to another" (Jayal, 2016, p. 177). Her analysis is based on the early life of the AAP, a party created in 2012, that successfully fought regional elections in 2013, briefly governed the city-state of Delhi, and fought national elections in

\footnotetext{
${ }^{1}$ In the Indian constitutional architecture Delhi has a specific status: since the adoption of the 69th Constitutional Amendment Act in 1991, Delhi has been a "quasi-state", officially called the National Capital Territory of Delhi (NCTD). Like the other 29 states of the Union, the NCTD has its own legislative assembly and government, but this government is weak because it has no control over three domains that, in this particular case, pertain to the Central government, namely land development, police, and law and order. The Chief Minister (CM) of Delhi is therefore closer to a city-manager; yet the centrality of Delhi in India's political life confers him/her a lot of media attention.
} 
2014, that time without much success. This was a period, therefore, when the party spent more time campaigning than governing.

I propose in this article to re-examine the qualification of the AAP as a populist party, with a specific focus on its conception of political representation, on the basis of fieldwork conducted in the next phase in the life of this party, what might be called its formative years as a party of government (and not only of opposition). This period starts in February 2015 with a massive electoral victory (the party wins 67 seats out of 70) and is marked by a series of "institutional improvisations and experiments" (Kaltwasser, 2014, p. 485), including two new participatory schemes. The analysis of these two schemes, I will argue, complicates the negative equation between populism and representative democracy posed by Jayal.

"Populism" is admittedly a problematic concept, as it is both overused and contested; but its very ubiquity invites us to engage with its descriptive and analytical value. The normative use of this concept dominates political commentary today: "populism" in the public debate is often the name of a "pathology of democracy" (Rosanvallon, 2011; Tarragoni, 2013), a qualification that implies negative judgement. In the Indian context, this concept was mostly associated, until recently, to Dravidian parties (that have been ruling the southern state of Tamil Nadu)always in a dismissive manner, to denounce a combination of personality cult, corruption and demagogy. But the rise to political dominance of the BJP, since 2014, has also been analysed in terms of right-wing populism (Jaffrelot, 2019; McDonnell \& Cabrera, 2019).

In the scholarly sphere, populism has been the focus of growing attention in the past two decades. While a review of this vast literature is beyond the scope of this article, I want to point at two broad, and largely overlapping, divides in such scholarship, in order to clarify where the present article stands.

The first divide concerns the very definition of populism as an object of empirical investigation. Many scholars today work with the "ideational approach" proposed by Cas Mudde, who defines populism as a:

Thin-centred ideology that considers society to be ultimately separated into two homogeneous and antagonistic camps, the 'pure people' and the 'corrupt elite', and which argues that politics should be an expression of the volonté générale (general will) of the people. (Mudde, 2004, p. 543)

Following the pioneering work of Margaret Canovan (1999), Mudde (2004) and Kaltwasser (2014) have inspired researchers to engage with the study of populism as a set of ideas that can be investigated through studies of discourse, rhetoric and claims (see, for instance, Bonikowski \& Gidron, 2016). However, other scholars have analysed populism through a focus not so much on ideas as on practices, in order to identify the characteristics (and consequences) of the exercise of power by pop- ulist parties: this is the case of Takis Pappas (2019) who studies variants of "ruling populism" (p. 82) in Europe and South America.

The second divide regards the assessment of the relationship between populism and democracy. Canovan (1999), Mudde and Kaltwasser (2013), but also Laclau (2007) consider that populism can have a positive impact on democracy insofar as it "can be both a threat to and a corrective for democracy" (Mudde \& Kaltwasser, 2013, p. 168). Indeed populism can be right-wing or left-wing; conservative or progressive (Bonikowski \& Gidron, 2016); exclusionary or inclusionary (Mudde \& Kaltwasser, 2013). This open stance however is criticised by Pappas, who defines populism as "democratic illiberalism" and considers that "populist rule leads to liberalism's decay and sometimes even to democratic breakdown" (Pappas, 2019, p. 82).

This article asks what the AAP says and does about political representation; it identifies populist tropesincluding de-emphasising representation-in the party's discourse, but also democratic innovations-ultimately redefining representation-in its practices, thus justifying an agnostic position regarding the relationship between populism and democracy.

In terms of methodology, the article is based, firstly, on political discourse analysis, the corpus being composed of a series of "texts and talks" (van Dijk, 1997) collected between 2013 and 2017: three electoral manifestoes (2013, 2014, 2015); six speeches by Arvind Kejriwal, the party leader; 24 semi-directed interviews with cadres, elected representatives and volunteers of the party, as well as four interviews with NGO workers and four interviews with bureaucrats working for the Delhi government (about one fourth of the corpus was in Hindi). Secondly, I could directly observe two meetings organised in the framework of the participatory devices under study, and since such meetings are often video-recorded, I could analyse the video-records of another five such meetings.

The article will first consider what the party says, and then what it does, in terms of political representation. Thus Section 2 will identify populist tropes in the official discourse of the AAP, including a de-emphasis on representation to the advantage of participation. Section 3 will describe the two main participatory schemes implemented by the AAP government since 2015, and show that they produce, in different ways, a magnification of the mediation work that is central to political representation at the local level in the Indian context. In the last section I will argue that the party has been developing, through these participatory schemes, a form of "inclusive representation" (Hayat, 2013) in which inclusion is linked to mobilization.

\section{A Discourse with Populist Overtones and a De-Emphasis on Representation}

The AAP was born from the "India Against Corruption" movement (2011-2012). As shown by Aheli 
Chowdhury ${ }^{2}$, even though this movement's discourse about politics was so negative that it was considered as "anti-democratic" by several observers (Chatterjee, 2011), it was also a critical moment in the construction of a new "representative claim" (Saward, 2010) by Kejriwal, the party leader, and his fellow organisers. The AAP, formally launched in October 2012, claimed to enter politics in order to "clean it from inside", to "change the rules", to "make politics more honest" and democracy more participative (an idea conveyed through the centrality of the term Swaraj-self-government-in the party's discourse). In December 2013, the young party contested elections to the Delhi Legislative assembly, and to everybody's surprise came second with 28 seats out of 70, behind the BJP (31 seats) but far ahead of the Congress party ( 8 seats). After some hesitation, the AAP decided to form the government with the support of Congress Members of the Legislative Assembly (MLAs). This first mandate was short: the alliance was a very fragile one, and the government resigned after only seven weeks. However, emboldened by its success in Delhi, the AAP went on to contest national elections in 2014, but won only four seats. The party then decided to focus again on Delhi, reinventing itself as the party of good, local, participatory governance (Tawa Lama-Rewal, 2014), and when new elections were organised in February 2015, it won with a historic majority (67 seats out of 70 ).

Let us first look at the rhetoric of the party, which is at its clearest in programmatic texts and talks, i.e., in election manifestoes and major addresses of the newly elected CM. Such rhetoric offers at the same time a critique of democracy as it exists and a demand for a better (or more) democracy. As Jayal rightly points out, this is typical of the "redemptive politics" associated to populism (Canovan, 1999). More precisely, one can identify six populist tropes in the official discourse of the party.

One, the struggle against corruption is central to the party's project. Thus Kejriwal (2014), in his resignation speech, declares:

They say we cannot govern. But in the past so many years, they couldn't audit the power companies, we did it in five days; in 65 years they couldn't reduce corruption, we did it in 49 days. We filed a FIR [First information Report] against corruption by Sheila [Delhi's former CM], Mukesh Ambani [a major industrialist] they say 'govern, don't do all this'. Come on, acting against the corrupt is true governance.

Two, in continuity with the anti-corruption movement, the party denounces political misrepresentation, in effect challenging, as Petra Guasti and Debora Almeida put it, "the legitimacy and authority of elected representatives" (2019, p. 154). Diagnosing the existence of a "representation gap" (Huber \& Ruth, 2017, p. 462) is indeed typical of anti-politics movements. The AAP thus asserts that political leaders, far removed from the ev- eryday reality of common people, are unable to take the right decisions:

While our country has achieved a system of free and fair elections in a minimum sense of the term, the mechanism of political representation does not offer meaningful and substantive choices to the citizens, nor does it provide a level playing field for political competition. (AAP, 2014)

Three, the governed (the ruled) are opposed to the governing (the rulers), in a recurrent contrast between the common man (aam aadmi)/common people (chote log, janta) and politicians (netas) and bureaucrats (babus):

Swaraj promised nothing short of self-rule: people's control over their destiny, power to decide on matters concerning their well-being, to direct the apparatus of power and hold rulers accountable. Swaraj is about rule by the people, not by netas or babus. (AAP, 2014)

However-and this is a first caveat regarding the populist nature of the party-it must be noted that the AAP is not critical of all elites-it does not target judges, journalists or intellectuals; therefore, it is not so much antiestablishment as anti-politics (Barr, 2009, p. 4).

A fourth populist feature of the party's discourse is that it conceives "the people" as a unified whole-the differences, inequalities and conflicts among individuals and groups are practically never mentioned. But at the same time, and this is a second caveat, the party is not concerned about the boundaries of such "people". Its conception is closer to plebs than to ethnos (Kaltwasser, 2014 , p. 480), In other words, the people is here defined by a (dominated) socio-economic condition, not by culture or identity; there is no "dangerous other" implied in such notion of "people", as opposed to the BJP's discourse for instance (McDonnell \& Cabrera, 2019, p. 487). Indeed the "socio-economic dimension of exclusion" (Mudde \& Kaltwasser, 2013, p. 167) is central in the party's discourse, suggesting that the "host ideology" (Huber \& Ruth, 2017, p. 466) of AAP's populism is closer to the Left than to the Right-even though the party carefully avoids conflating the "people" with the poor (only). In fact, the image of "the common man", offered as a substitute to more specific categories of the popular used by other Indian parties, such as the poor, Dalits, workers, etc., signals that the AAP refuses to engage into identity politics. There is an almost abstract quality of such image of the popular-almost only, because it does, even if unwittingly, betray the fact that women are strongly under-represented at all levels in the party.

The party's rhetoric emphasizes, fifthly, a common commonness between the people and the AAP government; it suggests a consubstantiality that flattens the verticality inherent in political power, and erases the phase of conquest of power by the party from its narrative.

\footnotetext{
${ }^{2}$ See her article in this thematic issue.
} 
Thus spoke Kejriwal (2015), after becoming CM for the second time, in February 2015:

Delhi again has an Aam Aadmi government...it's not me who has taken the CM's oath. All of you have taken this oath. It's not me who has become Delhi's CM. Every citizen of Delhi has become the state's CM.

However, even though the leader insists that he is himself a common man, there is only one leader (Wyatt, 2015). This is another central feature of populism, which is not explicitly present in the AAP discourse but very much so in its practice.

Elected representatives, too, must be like the people: in the relationship between representatives and their constituents, likeness is preferable to distinction. Thus, the party repeatedly emphasized its intention to put an end to "VIP raj [rule], VIP culture" (Kejriwal, 2014). Moreover-and this is a sixth characteristic of populist parties (Kaltwasser, 2014, p. 479) - the AAP sees representation in terms of an imperative mandate. In 2014, the party's manifesto asserts:

Aam Aadmi Party is contesting elections not merely to form the government but to fundamentally transform the system of governance. We believe that decisionmaking power resides with the people and should be exercised directly by them. In our vision of Swaraj, every citizen of India would be able to participate in decisions that affect their lives. People will make the decisions and elected representatives would implement them....Provisions of 'Right to Reject' and 'Right to Recall' (will) be introduced. (AAP, 2014)

The emphasis on participation, which is unique, in the Indian context, to the AAP, rests on the idea that democracy needs be made more participatory in order to be both more efficient and more democratic. Thus, elected representatives are supposed to take decisions not only on behalf of the people and for the people, but also with the people. What is being proposed is a kind of cogovernment. In his first address as CM, given in front of a huge crowd of supporters in December 2013, Kejriwal insisted on this image:

Our fight was never to make Kejriwal CM. It was to hand power back to the people. Today, the aam admi (common man) has won...friends, we must run Delhi together. The seven ministers won't run the government, officials won't run the government, police won't run it. We'll evolve a system where all 1.5 crore [15 million] people together run the government. (Kejriwal, 2013)

On the whole, while the party has a lot to say about participation, governance and government, statements about representation are rare. The rhetoric of the AAP emphasizes the misrepresentation produced by politics as it exists, that is, by the other parties; but it also deemphasizes political representation in its own vision for the future, insisting instead on participation. No positive representative claim follows, as is often the case (Guasti \& Almeida, 2019), the negative claim of misrepresentation. There is a "prescription for change" (Barr, 2009, p. 4) but it concerns participation, not representation.

\section{Participatory Practices and Magnified Mediation}

Looking at what the AAP has been doing since 2015 regarding its promise to develop participation, however, shows that the relationship between representation and participation is not a zero sum game. Indeed, the party implemented two participatory dispositives that gave birth to new forms of political representation: the mohalla sabhas (neighbourhood assemblies) and the SMC mahasabhas (School Management Committees' super assemblies).

The idea of the mohalla sabha is that of a micro local meeting-on the scale of a neighbourhood, i.e., about 5000 people in the context of Delhi-where local residents will discuss development works required in their area, and will together decide on a series of priorities in this regard. Between 2009 and 2015, this idea constantly evolved, as activists became party leaders and then ministers. From 2013 onwards, a small team of dedicated AAP cadres worked at improving its formula so as to find the right scale, the right frequency, and the right modus operandi.

A first step towards the institutionalization of the mohalla sabha was taken in the Spring of 2015, shortly after the AAP was voted to power for the second time, through a pilot experiment with participatory budgeting. This new experience was first conducted in a limited number of constituencies (11 out of 70 ), but all the resources at the disposal of the new government were invested in it. Thus, in each constituency, 30 to 40 mohallas were delimited, with a view to have a roughly equal number of residents, and as far as possible, some socioeconomic homogeneity. In order to organise the meetings in each neighbourhood, two "mohalla sabha coordinators" were nominated by the elected representative, the MLA. Their role was, before the meeting, to inform local people and encourage them to participate; during the meeting they had to moderate discussions between residents, but also between residents and officials representing the various concerned departments (in charge of water, horticulture, roads, etc.); and after the meeting they were in charge of following up and making sure that departments were working as per the priorities identified by the mohalla sabha.

On the basis of this pilot experience, the government prepared for the next round of participatory budgeting (scheduled for September 2016) in a more systematic manner: new NGOs were roped in to identify and train 6000 coordinators. In parallel, a detailed mapping of local infrastructure was conducted, along with 
a precise identification of the departments and offices in charge of these various local "assets". On the basis of this huge collection of information, a mobile application was conceived specifically for mohalla sabha coordinators, so that they could immediately identify the person to contact in case of an overflowing drain, broken light bulbs, potholes in the road, etc. This whole organisation was financially planned for in the framework of the Swaraj (self-government) Bill, presented by the AAP as its signature piece of legislation. However, the Swaraj Bill was never notified, because from May 2015 a peculiar institutional tussle developed between the Central government, dominated by the BJP and represented in the constitutional architecture of the city-state by the Lieutenant Governor, and the regional government headed by the AAP, thus severely constraining the room for manoeuvre of the latter.

Facing the virtual suspension of the Swaraj Bill, the team of AAP cadres who had been working on mohalla sabhas then decided to shelve the project and invest their energy in a domain less dependent on the power of the Lieutenant Governor: the 1024 government schools where the children of Delhi's poorest residents are enrolled. Indeed, these cadres saw the SMCs as a potentially significant site for participatory democracy. SMCs are planned for in the Right to Education Act, an ambitious policy adopted at the national level in 2009 but badly implemented in most parts of India. The Education Ministry of the Delhi government decided to take seriously the elections to renew SMCs, due in late 2016. According to the law, each school must have an SMC composed of 16 persons: the school principal; a teacher of the school; 12 parents elected by other parents; a social worker; and the MLA, that is, the local elected representative. The objective became to give SMCs a central role in the government's project to improve the quality of schools, through two innovations: firstly, the MLA was to be represented in each SMC by an "MLA representative", nominated by him/her; secondly, several NGOs were roped in to train the 14,000 newly elected "parent members" of SMCs, to help organize SMC mahasabhas (super assemblies), and to follow up work.

SMC mahasabhas are large meetings where the SMCs of all the government schools of a constituency will present their grievances and demands to officials of several concerned departments (Education, but also Water, Police...) in the presence of the local MLA. These mahasabhas, even though they focus only on one sectoreducation-and involve only one category of citizensparents-clearly are a continuation of mohalla sabhas. They offer another version of the organised confrontation between citizens and the administration, moderated by the elected representative. However, lessons have been learnt after the pilot experiment with mo- halla sabhas, and one can observe the results of organisational learning. For instance, much more attention is devoted to equipping parent members of SMCs with the resources necessary for a real dialogue. Thus, each SMC mahasabha is preceded by a long preparation work that involves the training of parent members, the repeated solicitation of bureaucrats, the diffusion of information in an adequate form, etc. As a result, SMC mahasabhas have become effective platforms for grievance redress ${ }^{3}$.

Both the short-lived participatory budgeting and the more successful SMC mahasabhas have implications for political representation in Delhi. In both cases indeed one can observe a redefinition of mediation work, as such mediation is magnified in two different ways.

Firstly, the role of the elected representative as mediator between his/her constituents and the state administration, a role considered as essential in the Indian context, takes on a new dimension because of the public nature of the meetings of mohalla sabhas and SMC mahasabhas. Such meetings are staged in a way that favourably highlights the central position of the MLA in between aggrieved citizens and a complex bureaucracy, as he/she not only monitors the discussion, but also intervenes to remind bureaucrats of their obligations visà-vis citizens. Thus, both mohalla sabhas and SMC mahasabhas have become possible sites for a political performance by the MLA, who both mediates and displays his/her mediation, as explained by an NGO worker in charge of preparing SMC mahasabhas:

The SMC sabhas (assemblies) are a fantastic political platform for MLAs....Because he or she can reprimand officers in front of the parents, the parents will applaud, think "he is a tough guy, he is speaking for us" and most of the time actually the MLA...doesn't do much, but the SMC sabha becomes the platform to show that "look, I care so much"....We don't mind it too much, because our work is also getting done, for us also its important that the departments do get reprimanded...but we are very mindful the fact that it is a very political platform, it's a platform that helps the Aam Admi Party electorally as well. (Interview, Delhi, 2017)

Secondly, mediation work is expanded through the nomination of "mohalla sabha coordinators" and then "MLA representatives". We have seen that in the aftermath of the pilot participatory budgeting, $6000 \mathrm{MS}$ coordinators were selected before the whole project was suspended. And since 2016, around 1000 MLA representatives have been nominated to take part in SMCs.

Today the latter are active even beyond this specific participatory scheme: several MLAs told me how their "representatives" are nominated, trained and involved in

\footnotetext{
${ }^{3}$ The empowerment of school management committees is only one part of the Delhi government's education policy, that also includes a significant increase in the budget allotted to the sector, building school infrastructure (classrooms, toilets, etc.) and reforming teachers' training. This consistent effort since 2015 has definitely improved outcomes: results for the 2018 exams at the end of class 12 revealed that the pass percentage was better in government schools (91\%) than in private institutions (88\%). For a balanced assessment of the AAP government's education policy, see Dhingra (2019).
} 
local governance in a more or less formal manner. It is important to note that this new character is recognised by bureaucrats-one of them indeed mentioned "the local representative" to refer not to the MLA, but to his nominee. The use of vocabulary is interesting here: on the one hand, the elected representative is never called "representative" (or pratinidhi) by my interviewees, who will mention only the "MLA", sometimes the "vidhayak" (legislator), very rarely the "neta" (leader). On the other hand, the person nominated by the MLA to represent him/her, even if he is sometimes named "MLA proxy" or "MLA nominee" by party cadres, is most often called "MLA representative".

The MLA representative is always a party volunteer, someone who has time to spare for this work and who will know how to speak to bureaucrats. It's almost always a man, either somebody who has a business that can run without him, or a retired person.

What does he do? In the context of SMCs, his first function is a symbolic one-he signals that SMCs have to be taken seriously, as explained by a party cadre:

Parents often feel disempowered...in schools, parents often could not even enter schools, were turned away by the guard at the door. What really helped was the fact that there was a representative from the MLA's office (in the SMC), it meant that there is someone who is politically empowered and therefore...they could help ensure that the governmental administrative structure gives some recognition to these parents. So if someone is coming from MLA's office, they would obviously be served tea in the same kind of cups as the principal, therefore the parents also could be served in the same plates, so that prevented lots of class bias that used to exist even in the defunct (SMCs).... have heard about how in some MCD [Municipal Corporation of Delhi] schools, the principal would sit on the chair and the parents sit on the floor in SMC meetings. So the presence of the MLA representative ensured that there was better treatment of SMCs, because of the MLA, that is, political empowerment, that gives to the parents more of a voice. (Interview 2017)

The second function of the MLA representative is to work on local peoples' grievances regarding their area:

We solve grievances....Any sort of grievances. Now MLA's power lies in specific areas. For instance...there is Electricity Department, then there is Water Department...and Public Works Department [PWD]....So we deal with all these issues....Essentially our (mobile) numbers are with a lot of people, because we are representatives in our specific areas and also as a whole in the constituency. (Interview with MLA representative, 2017)

His third role is that of a liaison officer: he communicates information from the MLA to local residents, but also- and this is significant regarding political representationhe talks to the MLA on behalf of the residents as a collective:

Their job is basically a postman, so whatever work is needed in their area, they will let me know that this is the high priority work, for example at $1 \mathrm{pm}$ today, we have a meeting at Delhi Jal Board (Water Department), so I will go and meet the officer there. So, seven, eight volunteers will be available there, so we will be discussing more the budget that I have got, let's say 2 crores (20 million rupees), and I have works which are lined up which are 7 crores....So we will all sit and we will prioritize, let us give 20 lakhs (two million rupees) to this, 7 lakhs to this, 8 lakhs to this... because I don't know what is high priority in different areas. (Interview with MLA, 2017)

Thus the MLA representative is expected to intercede/intervene on behalf not of individuals, but of a collective: either the constituency of the MLA as a whole, when he acts as proxy of the MLA in a meeting with bureaucrats; or one portion of this constituency, when he acts as the spokesperson of a neighbourhood in a meeting with the MLA. Because the MLA representative is somewhat formally given the role of "speaking for" a collective (to paraphrase Hanna Pitkin) we can consider that he does perform some political representation. However, the MLA and his/her representative have clearly different mandates: while the MLA is an elected representative, his/her nominee is a delegated one.

AAP cadres present MLA representatives as crucial actors in the party's project of decentralizing decision-making. Except in the Education sector, however, MLA representatives are actors of deconcentration rather than decentralization. Through the nomination of his/her 30 to 40 "representatives", the MLA distributes power only to party volunteers or supporters; and the power of each nominee is only, as I said, a delegation of his/her own power, which makes it very difficult for MLA representatives to contest the MLA's vision or decisions. Indeed, all interviewees insisted on the need to "act", "solve", and "get things done"; there was no mention of debates within the group formed by the MLA and his/her representatives, let alone of dissension.

So, are MLA representatives any different from the swarm of party workers hanging around party offices in all Indian metropolises? Beyond their new name, are they not the same, well known figures of everyday politics, described in the works of political anthropologists studying urban India? (See for instance Berenschot, 2010; Björkman, 2014; and Witsoe, 2011). There is obviously one common feature: just like other parties, the AAP uses the semi-formal position of MLA representative to distribute symbolic resources to its supporters, i.e., the social prestige that comes from being associated to the MLA and speaking on a regular basis to bureaucrats. 
One difference, however, is the tentative formalization of the relationship between the MLA and the MLA representative. There will be a poster put up in the office of the MLA, displaying the names of his/her representatives along with their phone number and the departments of which they are respectively "in charge". There can also be a letter written by the MLA, specifically requesting a department to accept Mr. $\mathrm{X}$ as his/her representative, as explained by the secretary of an MLA:

We have here a dedicated team of 20 people, for electricity issues, MCD issues, PWD issues, Forest Department...this gentleman looks after issues related to the Delhi Jal Board (Water Department)....This gentleman coordinates with everyone....and MLA has officially sent a letter to the department concerned, (saying) that "I authorize so and so, his mobile number so and so, to speak, coordinate and communicate with our department officials on my behalf on issues related to (our) Assembly constituency". He's given a letter to the concerned Minister and asked "please advise your officials to cooperate with them." (Interview, Delhi, 2016)

This semi-institutionalization of MLA representatives, this emphasis on a transparent deconcentration of the MLA's mediation work, precisely demonstrates a will to differentiate MLA representatives from the multiplicity of mediators that characterises Delhi's governance (Tawa Lama-Rewal, 2011) such as party workers, "informal leaders", or the self-appointed representatives of Resident Welfare Associations.

\section{Making Representation Inclusive}

Another, more important difference between the AAP and other political parties is the magnification of mediation achieved through (i) its public performance by MLAs and (ii) its expansion by MLA representatives. In the participatory devices described above, elected representatives "speak for" the people, but also with the people, offering an example of what Samuel Hayat calls "inclusive representation":

Political representation can be called inclusive when it enables citizens to fight against exclusion from professional politics by acquiring (its) language and by using it to intervene in decision-making processes from which they are excluded. This form of the inclusive use of representation can be designated as the inclusion of citizens through their politicization. (Hayat, 2013, p. 119)

The empowerment of SMCs, especially through the organisation of SMC mahasabhas, is arguably a case of such "inclusion by politicization". An NGO worker who coordinated the organisation of several SMC mahasabhas thus evokes a major, if intangible result of these meetings:

SMCs don't just serve as the grievance redressal platform, they are also somehow a means to give people a sense that the state is listening to them, and that is something that does not happen in India too often. Indians don't engage too much with the state, their engagement with the state largely happens only during the election. That is the only time they feel that the state exists, and state exists for them. Otherwise Indians usually see the state as a somewhat repressive, autocratic power, which they don't have anything to do with. But here it is a platform where they see all the officials who are responsible for whatever their school is supposed to be running, and here is the platform where they have the power to shout at officials and tell them that "you have not done your work", because when they go to a government office to get the work done, they are at a position of inferiority and they are never listened to... but here the official is coming to them, and here is a platform which is exclusively for them. (Interview 2017) 4

While SMC parent members are formally trained in order to play their role in an effective manner, MLA representatives receive more informal (but not necessarily less effective) "training sessions", as explained by an MLA:

We do have training sessions, so they (MLA representatives)...know, basically what are the stages of getting the work done....What will happen is that we will call them to the officers' meeting, slowly they will understand that this is how things will work...like, these three four people here, they all are party volunteers...so they'll just sit here like a fly on the wall, and grasp whatever they can. (Interview 2017)

When I asked MLA representatives how bureaucrats reacted to their intervention, here is what one of them told me:

They (bureaucrats) never listened to us because we were amateurs, you know? When we came in, we didn't understand the structure. So the first two years we learned how to speak to them. We learned how to get the work done by them. Because they also slowly realised that we don't really have any authority over them...but now they don't want to get into that mess to be very honest. So work happens. Because, they know at the end of the day, we can very much call them and then get the work done. So it is only going to elongate the time of the whole process. (Interview 2017)

\footnotetext{
${ }^{4}$ This description suggests that the SMC mahasabha is the latest avatar of the jan sunwai (public hearing), a form of mobilization cum platform for grievance redressal whose specific emotional dynamics helps "restore the citizenship" of its participants (Tawa Lama-Rewal, 2018).
} 
Where should we place MLA representatives in the representative system of Delhi politics? The distinction made by Hayat between two modes of inclusion by politicization, i.e., internal and external inclusion, is heuristic:

We will distinguish between internal inclusion, based on actual mechanisms of representative government, and external inclusion, which relies on the construction of forms of representation outside the institutions of representative government. (Hayat, 2013, p. 118)

The difficulty of applying this distinction to the Delhi case results from-and highlights - the fact that the AAP government has made the boundaries between formal and informal mediation/representation, and between representation and participation, even more blurred than they used to be when the Congress party was in power in the city-state. Mohalla sabhas and empowered SMCs might well exemplify "external inclusion", but the semi-formal MLA representative is more difficult to categorise. On the one hand the very concept of "MLA representative", that is, "representative's representative", implicitly emphasises elections as the principal source of legitimacy (directly for the MLA, indirectly for his representatives). On the other hand, MLA representatives carry mostly the informal (but nevertheless important) part of the mediation work assigned to the MLA.

This merging of "internal" and "external" inclusion might be called "inclusion as mobilization". Indeed, the representative claim of MLAs, in the AAP, is a mobilizing one. The modus operandi of mohalla sabhas as well as SMC mahasabhas signifies that the legitimacy of the local elected representative proceeds not only from his/her election, but also from his/her capacity to mobilize constituents, to have them participate in the devices set up by the government. In other words, the MLA embodies popular sovereignty, but not completely; he/she needs "the people" to be physically present at his/her sides in order to completely (that is, symbolically as well as juridically; for a discussion of the different meanings of political representation, see Sintomer, 2013) represent his/her constituency. As an MLA put it:

We represent people and the premise of our power is based on the people having elected us, so obviously even today whenever there is some work which is getting delayed, I can talk to an officer and tell him this is what the mohalla voted for; there have been instances where I've told residents of the mohalla to come with me for that meeting, so I can put further pressure on that officer, that "I have these 50 people from the mohalla sitting over here, outside your office, please give them an answer." (Interview 2016)

This conception of the representative as mobilizer is both a legacy of the past avatar of the party as a (anticorruption) movement, and central to a political strat- egy that could be described as permanent canvassing. Indeed, the semi-institutionalization of some 3,000 MLA representatives would obviously consolidate the party's presence and visibility on the whole territory of Delhi. The selection and nomination of MLA representatives is a way to keep the AAP's army of volunteers busy, to reward loyalties, to offer incentives. It consolidates the MLA's - and therefore the party's-hold on the constituency. However political convictions are not necessarily at odds with political compulsions: in this case, the party arguably wants to mobilize people both because this will increase pressure on local authorities to get work done, and because it should be an asset in the next elections.

\section{Conclusion}

Seven years after its creation, the AAP is no longer the "unidentified political object" that it used to be (Roy, 2014), even though it has been, since 2015 , in a situation that is at the same time uniquely favourable (it won 67 seats out of 70 in Delhi) and exceptionally constraining (its conflict with the Lieutenant Governor has resulted, since 2016, in near institutional paralysis). I have shown that the party's discourse reveals many affinities with populism, including a denunciation of misrepresentation, and a de-emphasis on representation in a more positive sense. The promotion of participation both in the discourse of the party and in its practices (once it formed the government) confirms the proximity, underlined by Margaret Canovan (1999, p. 14), between populisms and what she calls "participatory radicalisms" - even though the AAP has consistently valued decision more than deliberation, and will more than judgement.

Looking at the two main participatory dispositives implemented by the party complicates the negative equation between populism and representative democracy posed by Jayal, who considered that in its early years at least, the party, while it "formally accept(ed) the framework of representative democracy...simultaneously work(ed) to undermine it" (Jayal, 2016 , p. 178). I have argued that the role given to the MLA in mohalla sabhas and in SMC mahasabhas, as well as the semi-institutionalization of MLA representatives, both magnify the mediation work that is central to political representation, and reassert that election is the main (if not exclusive) source of legitimacy. Moreover, mohalla sabhas and SMC mahasabhas are innovations that can doubtlessly be called "democratic", even if imperfectly so. Finally, the conception of the elected representative as mobilizer is central to a form of "inclusive representation".

\section{Acknowledgments}

This research is part of a collective research project jointly funded by ANR and DFG, called CLAIMS (https://claims.hypotheses.org/68); it greatly bene- 
fited from discussions within the team. I also want to thank the two anonymous reviewers as well as Brigitte Geissel and Petra Guasti for their insightful comments and suggestions.

\section{Conflict of Interests}

The author declares no conflict of interests.

\section{References}

Aam Aadmi Party. (2014). Aam Aadmi Party: National manifesto 2014. Aam Aadmi Party. Retrieved from https://aamaadmiparty.wordpress.com/2014/ 04/03/aam-aadmi-party-national-manifesto-2014

Barr, R. R. (2009). Populists, outsiders and antiestablishment politics. Party Politics, 15(1), 29-48. https://doi.org/10.1177/1354068808097890

Berenschot, W. (2010). Everyday mediation: The politics of public service delivery in Gujarat, India. Development and Change, 41(5), 883-905. https://doi.org/ 10.1111/j.1467-7660.2010.01660.x

Björkman, L. (2014). 'Vote banking' as politics in Mumbai. In A. Piliavsky (Ed.), Patronage as politics in South Asia (pp. 176-195). Cambridge, MA: Cambridge University Press.

Bonikowski, B., \& Gidron, N. (2016). The populist style in American politics: Presidential Campaign discourse, 1952-1996. Social Forces, 94(4), 1593-1621. https:// doi.org/10.1093/sf/sov120

Canovan, M. (1999). Trust the people! Populism and the two faces of democracy. Political Studies, 47(1), 2-16. https://doi.org/10.1111/1467-9248.00184

Chatterjee, P. (2011). Against corruption = Against politics. Retrieved from https://kafila.online/2011/ 08/28/against-corruption-against-politics-parthachatterjee

Dhingra, K. (2019, February 23). As AAP turns government schools around, questions about learning linger. The Wire. Retrieved from https://thewire.in/ education/as-aap-turns-government-schoolsaround-questions-about-learning-linger

Guasti, P., \& Almeida, D. R. (2019). Claims of misrepresentation: A comparison of Germany and Brazil. Politics and Governance, 7(3), 152-164.

Hayat, S. (2013). Inclusive representation. Raisons Politiques, 50(2), 115-135.

Huber, R. A., \& Ruth, S. P. (2017). Mind the gap! Populism, participation and representation in Europe. Swiss Political Science Review, 23(4), 462-484. https://doi. org/10.1111/spsr.12280

Jaffrelot, C. (2019). L'Inde de Modi: National-populisme et démocratie ethnique [Modi's India: Nationalpopulism and ethnic democracy]. Paris: Fayard.

Jayal, N. G. (2016). Contending representative claims in Indian democracy. India Review, 15(2), 172-195. https://doi.org/10.1080/14736489.2016.1165556

Kaltwasser, C. R. (2014). The responses of populism to Dahl's democratic dilemmas. Political Studies, 62(3), 470-487. https://doi.org/10.1111/1467-9248. 12038

Kejriwal, A. (2013). Kejriwal's address after oath taking. The times of India. Retrieved from https:// timesofindia.indiatimes.com/assembly-elections2013/delhi-assembly-elections/Remember-werehere-to-serve-never-be-arrogant-Arvind-Kejriwal/ articleshow/28075560.cms?prtpage $=1$

Kejriwal, A. (2014). Arvind Kejriwal's speech in the Legislative Assembly, January 2014. Retrieved from https://www.youtube.com/watch?v=E4Vxvr18UNQ

Kejriwal, A. (2015). Kejriwal's address after becoming CM for the second time. Retrieved from https://www. youtube.com/watch?v=NAViJaoXpag

Laclau, E. (2007). On populist reason. London: Verso.

McDonnell, D., \& Cabrera, L. (2019). The right-wing populism of India's Bharatiya Janata party (and why comparativists should care). Democratization, 26(3), 484-501. https://doi.org/10.1080/13510347. 2018.1551885

Mudde, C. (2004). The populist zeitgeist. Government and Opposition, 39(4), 541-563. https://doi.org/10. 1111/j.1477-7053.2004.00135.x

Mudde, C., \& Kaltwasser, C. R. (2013). Exclusionary vs. inclusionary populism: Comparing contemporary Europe and Latin America. Government and Opposition, 48(2), 147-174. https://doi.org/10.1017/gov. 2012.11

Pappas, T. S. (2019). Populists in power. Journal of Democracy, 30(2), 70-84. https://doi.org/10.1353/ jod.2019.0026

Rosanvallon, P. (2011). Penser le populisme. La Vie des Idées. Retrieved from http://www.laviedesidees.fr/ Penser-le-populisme.html

Roy, S. (2014). Being the change. The Aam Aadmi party and the politics of the extraordinary in Indian democracy. Economic and Political Weekly, 49(15), 45-54.

Saward, M. (2010). The representative claim. Oxford: Oxford University Press.

Sintomer, Y. (2013). Les sens de la représentation politique: Usages et mésusages d'une notion. Raisons Politiques, 2(50), 13-34.

Tarragoni, F. (2013). La science du populisme au crible de la critique sociologique: Archéologie d'un mépris savant du peuple [The science of populism as assessed through the prism of sociological critique: An archeology of a knowing contempt for the people]. Actuel Marx, 2(54), 56-70. https://doi.org/10.3917/ amx.054.0056

Tawa Lama-Rewal, S. (2011). Urban governance and health care provision in Delhi. Environment and Urbanization, 23(2), 1-19.

Tawa Lama-Rewal, S. (2014). Les défis extraordinaires du "Parti de l'homme ordinaire". Retour sur les élections Indiennes de 2014. Noria. Retrieved from http:// www.noria-research.com/les-defis-extraordinairesdu-parti-de-Ihomme-ordinaire-retour-sur-les- 
elections-indiennes-de-2014

Tawa Lama-Rewal, S. (2018). Public hearings as social performance: Addressing the courts, restoring citizenship. South Asia Multidisciplinary Academic Journal, 17. https://doi.org/10.4000/samaj.4413

van Dijk, T. A. (1997). What is political discourse analysis? Belgian Journal of Linguistics, 11(1), 11-52. https:// doi.org/10.1075/bjl.11.03dij
Witsoe, J. (2011). Corruption as power: Caste and the political imagination of the postcolonial state. American Ethnologist, 38, 73-85. https://doi.org/10.1111/ j.1548-1425.2010.01293.x

Wyatt, A. (2015). Arvind Kejriwal's leadership of the Aam Aadmi party. Contemporary South Asia, 23(2), 167-180. https://doi.org/10.1080/ 09584935.2015 .1025038

\section{About the Author}

Stéphanie Tawa Lama-Rewal is a political scientist who studies Indian democracy through three major themes: group (especially women's) representation; participatory experiments; and urban governance. Her recent publications include Les Avatars de la Participation en Inde. Formes et Ambiguïtés de la Démocratie Participative (Avatars of Participation in India. Forms and Ambiguities of Participatory Democracy, Paris, Editions du Croquant, 2018) and (co-edited with Amélie Blom) Emotions and Mobilisations in South Asian Politics (Delhi, Routledge, 2019). 